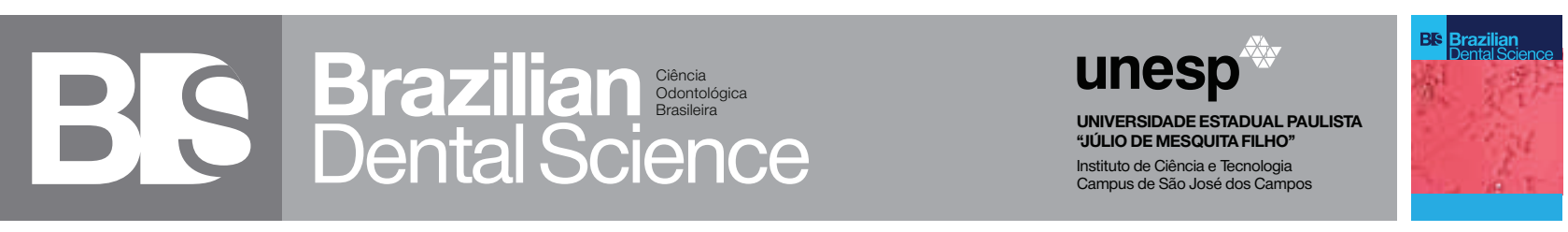

\title{
Effectiveness of low level laser therapy in the treatment of TMD myalgia: two case reports
}

Eficácia do laser de baixa potência no tratamento da DTM: dois relatos de casos

\begin{abstract}
Natália Cortez GUTIERREZ ${ }^{1}$, Heleine Maria hagas RÊGO' ${ }^{1}$, Maria Ângela Lacerda Rangel ESPER ${ }^{1}$, Pedro Henrique CORAZZA², Carolina da Silva Machado MARTINELLI ${ }^{2}$, Fernanda CAMPOS ${ }^{2}$, Carlos Rocha Gomes TORRES ${ }^{1}$, Sérgio Eduardo de Paiva GONÇALVES ${ }^{1}$ 1 - Institute of Science and Technology - UNESP - Univ Estadual Paulista - São José dos Campos (SP) - School of Dentistry - Restorative Dentistry Department - São José dos Campos - SP - Brazil.

2 - Institute of Science and Technology - UNESP - Univ Estadual Paulista - São José dos Campos (SP) - School of Dentistry - Dental Materials and Prosthodontics Department - São José dos Campos - SP - Brazil.
\end{abstract}

\section{ABSTRACT}

Objective: To report two cases of low level laser therapy used in the treatment of muscle pain caused by temporomandibular disorders (TMDs). Methods: Two patients were selected and subjected to eight applications of low level laser therapy (diode - wavelength of $795 \mathrm{~nm}$, energy density of $8 \mathrm{~J} / \mathrm{cm}^{2}$, power of $120 \mathrm{~mW}$, 66 se per point). Laser was punctually applied on masseter and temporalis muscles bilaterally. Three methods were used to evaluate the effectiveness of treatment: pressure algometer, visual analog scale (VAS) and maximal mouth opening. Each measurement was performed before and after the laser therapy session. The results were subjected to statistical analysis (ANOVA two factors and Tukey's test, $\alpha=$ 0.05). Results: For both patients, no significant difference was found between the results obtained with the algometer, before and after laser application, within each session. VAS results showed a tendency to lower values after laser application. In both cases, the highest values obtained by the pressure algometer were found between the days 9 (fourth application) and 16 (sixth application). Both patients had an improvement on mouth opening. Conclusions: The assessment methods used were quite practical to register the pain before and after treatment. Therapy with low level laser seems to have a beneficial effect for the masticatory muscles pain.

\section{KEYWORDS}

Maximal mouth opening; Pressure algometer; TMD; VAS.

\section{RESUIMO}

Objetivo: relatar dois casos do uso do laser de baixo potência no tratamento da dor muscular causada pela disfunção temporomandibular (DTM). Métodos: Dois pacientes foram selecionados e submetidos a oito aplicações de laser de baixa potência (diodo - comprimento de onda de $795 \mathrm{~nm}$, densidade de energia de $8 \mathrm{~J} / \mathrm{cm}^{2}$, potência de 120 $\mathrm{mW}, 66$ segundos por ponto). O laser foi aplicado pontualmente nos músculos masseter e temporal bilateralmente. Três métodos foram utilizados para avaliar a eficácia do tratamento: algômetro de pressão, escala visual analógica (VAS) e abertura máxima da boca. Cada medição foi realizada antes e após a sessão de terapia com laser. Os resultados foram submetidos à análise estatística (ANOVA dois fatores e teste de Tukey, $\alpha=0,05$ ). Resultados: Em ambos os casos, não foi encontrada diferença significativa entre os resultados obtidos com o algômetro antes e depois da aplicação do laser dentro de cada sessão. Os resultados com o VAS mostraram uma tendência a reduzir os valores após a aplicação do laser. Foram encontrados os maiores valores obtidos pelo algômetro de pressão entre os dias 9 (quarta aplicação) e 16 (sexta aplicativo), em ambos os casos. Ambos os pacientes tiveram uma melhora na abertura da boca. Conclusões: Os métodos de avaliação utilizados foram bastante prático para registrar a dor antes e após o tratamento. A terapia com laser de baixa potência parece ter um efeito benéfico para a dor músculos mastigatórios.

\section{PALAVRAS-CHAVE}

Abertura da boca máxima; Algômetro de pressão; DTM; VAS. 


\section{INTRODUCTION}

$\mathrm{T}$

emporomandibular disorders (TMD) are characterized by tenderness of facial muscles, headaches, click of the joint and limitation of mandibular movements [1-3]. No factor should be considered individually as a TMD causer because its etiology is multifactorial. However, there are some risk factors: gender (female), age (between 20 and 40 years), genetic, and parafunction (presence of bruxism and clenching) [4-7]. TMD usually affects the masticatory muscles and/or temporomandibular joint, and is often associated with psychological disorders and malocclusion [1,2,8-12]. The American Academy of Orofacial Pain (AAOP) recently divided TMD into two groups: Muscular TMD and Articular TMD [13].

The TMD diagnosis is usually made by anamnesis, physical examination and laboratory tests. After the diagnosis, the professional should control the pain of the patient using medication, counseling (changing habits), heat therapy, transcutaneous electrical nerve stimulation (TENS), muscle exercises, low level laser therapy (LLLT) or combination of different treatments $[2,8,14]$. The low level laser therapy (LLLT) is a non-invasive treatment that does not cause side effects [2]. A biomodulatory effect occurs on cells and tissues with this treatment, promoting an analgesic effect, anti-inflammatory and muscle relaxant [14-17]. Therefore, it has been used especially in cases of pain of the masticatory muscles, neck and shoulders [18].

However, to prove the effectiveness of this therapy, it is necessary to use pain measurement methods, as visual analog scale (subjective method) [19-25], maximum mouth opening and the pressure algometer applied on specific points of the face called trigger points (objective methods) [19,26-29]. These points are described as sensitive circumscribed nodules that are part of a palpable band of muscle fibers. The pain of myofascial trigger point has been reported as the most prevalent cause of painful symptoms in TMD [30].

The aim of this study is to report two cases of low level laser therapy used on the treatment of muscle pain caused by TMD. Besides the difficulties, consistency and relationship among different methods of measurement will be discussed.

\section{MATERIAL AND METHOD}

This study was developed by post-graduate students and professors of the Laser discipline, using the facilities of prosthodontics clinic of Institute of Science and Technology of São José dos Campos - São Paulo State University (UNESP). Two patients already registered on the waiting list for treatment at Occlusion and Temporomandibular Joint Center were selected (patient 1 and patient 2). Criteria for inclusion in the study were: presence of muscle pain in the masseter and temporalis muscles, presence of at least 20 teeth in the mouth and availability to the treatment. Patients were excluded if there were presence of: cancerous lesion, hypo or hyperthyroidism, neurological disorders and pacemaker. Patients agreed to attend all appointments and refrain from using analgesics, anti-inflammatory, anxiolytics, anti-depressants and/or muscle relaxants during treatment period. Patients signed an informed consent form, accepting the terms of the investigation.

Firstly, the patients were submitted to anamnesis through a form composed by patient identification, medical and disease history. The clinical evaluation was performed through inspection, palpation of the muscles involved and functional examination of the temporomandibular joint (TMJ). The treatment was performed twice a week for four weeks. Each patient received a total of eight applications of low level laser. Laser was applied punctually, perpendicular and in contact with the skin surface. The procedure was done bilaterally on potential trigger points located in the masseter and temporalis muscles, as shown in Figure 1, totaling 10 points per patient. These points were selected based on the literature [30] and marked with a ballpoint pen by the same operator. The patients were treated with diode laser (Laser Easy, Clean Line Ind. e Com Prod. Odontológicos Ltda., Taubaté, SP, Brazil) with wavelength of $795 \mathrm{~nm}$, energy density of $8 \mathrm{~J} /$ $\mathrm{cm}^{2}$, average power density of $63.6 \mathrm{~mW} / \mathrm{cm}^{2}$, beam area of $5.3 \mathrm{~cm}^{2}$ and power level of $120 \mathrm{~mW}$. Continuous emission was done for 66 seconds per point of application [31]. Following the biosafety rules for laser application, the equipment was protected by a plastic film, and the volunteer and the professional used safety glasses during the phototherapy. 


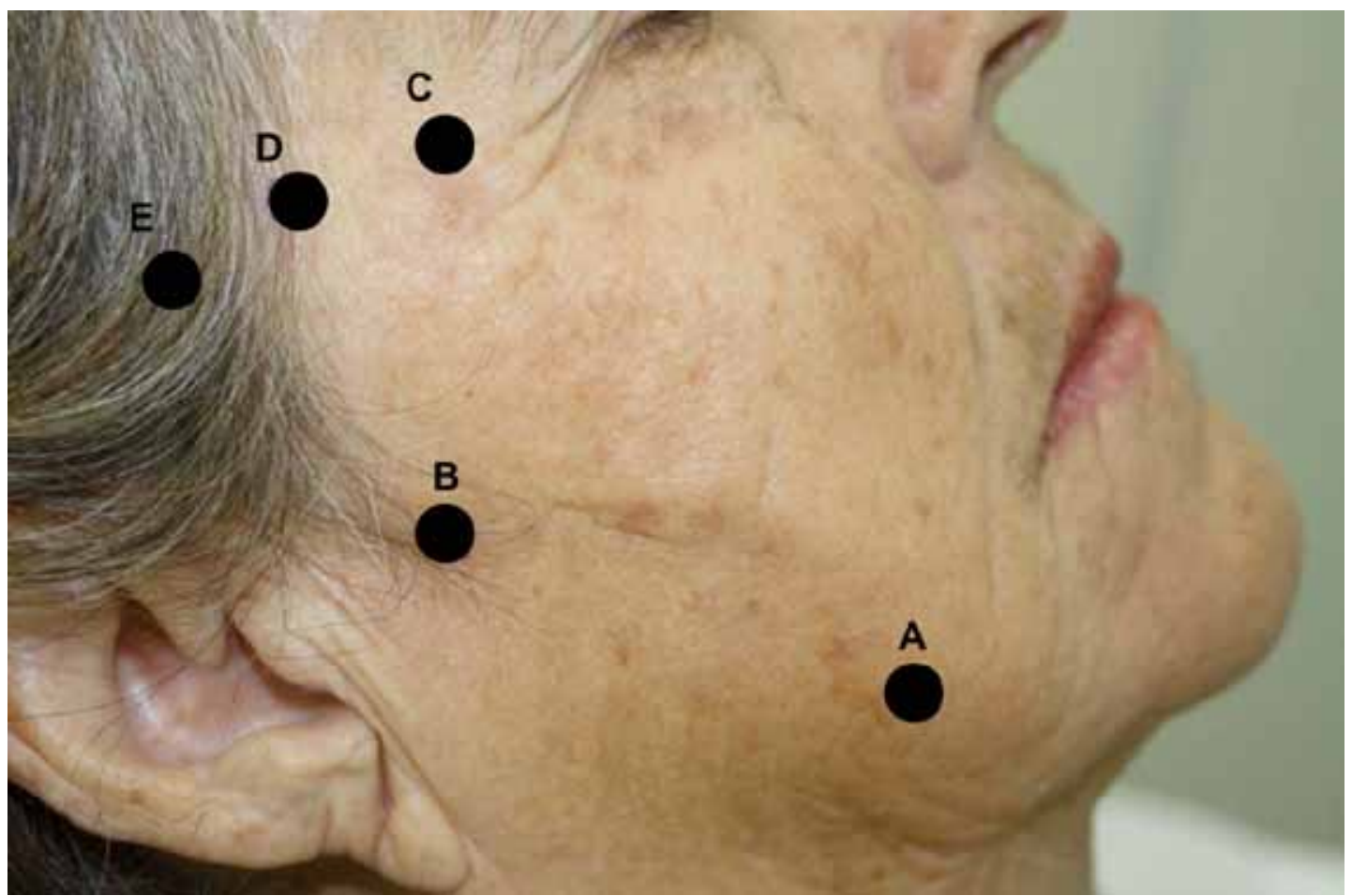

Figure 1- Schematic trigger points of laser irradiation: (A) lower portion of the surface layer of the masseter muscle; (B) posterior upper layer of the deep portion of masseter, bellow TMJ; (C) anterior portion of the temporal muscle; ( $\mathrm{D}$ and $\mathrm{E}$ ) intermediate portion of the temporal muscle.

Three methods were used to evaluate the effectiveness of the treatment: pressure algometer, visual analog scale (VAS) and maximal mouth opening. Each measurement was performed before and after each laser therapy session.

\section{Pressure Algometer}

The pressure algometer (Force Dial Algometer - Wagner Instruments, CT, EUA) is an instrument composed by a pressure analog indicator (in kgf) and a pressure tip applicator, which contact with the patient's skin (Figure 2). All measurements were performed by the same operator, at the same points where the laser was applied.

To measure the patient sensitivity to pressure pain, arithmetic average of the 10 obtained values (10 points) was calculated for each session, before and after laser therapy, totaling 16 averages for each patient. Data obtained on each day of measurement were statistically compared using 2-way ANOVA and Tukey test $(\alpha=0.05)$.

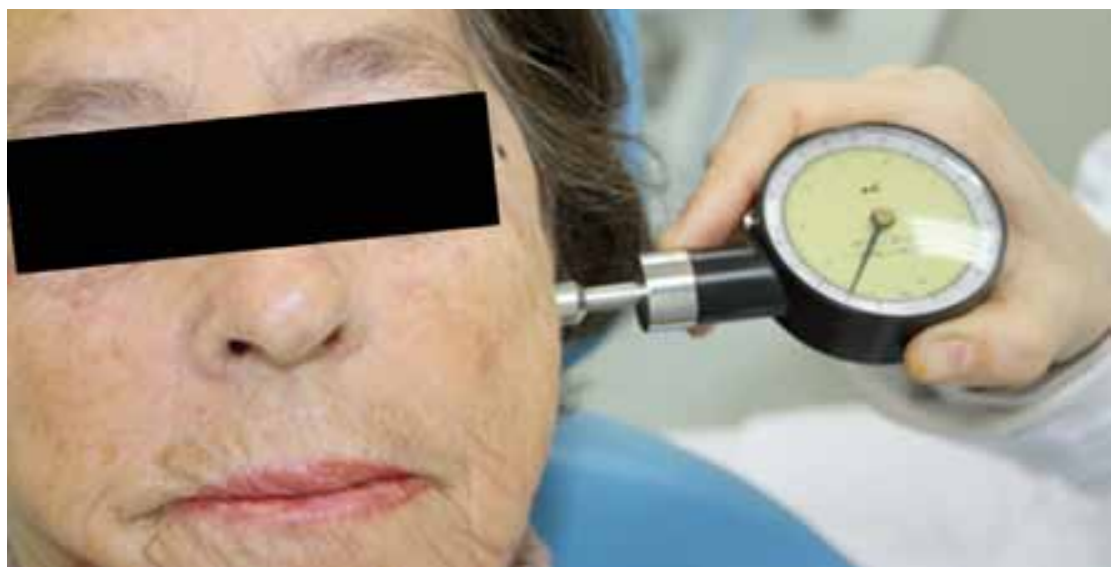

Figure 2 - Algometer being used for measurem. 


\section{Visual Analog Scale (VAS)}

The Visual Analog Scale (VAS) consisted of a 100 millimeters long non-graded ruler with descriptors representing the extremities: left "no pain" and right "unbearable pain". The distance between the point corresponding to the pain intensity, as indicated by the patient, and the left end of the scale determined the VAS value in millimeters. Higher scores indicate higher levels of pain intensity.

\section{Maximal Mouth Opening}

Linear measurements of maximum mouth opening were recorded with a digital caliper (727 Starrett, Itu, SP, Brazil). The distance between the incisal edge of the maxillary central incisors and the incisal edge of the mandibular central incisors (mm) was measured, after which the patient was asked to open his mouth as wide as possible, even if it generated pain. The obtained value was added to the vertical overlap length of the patient.

\section{RESULTS}

\section{Patient 1}

Table 1 presents the mean, standard deviation and homogeneous groups for the algometer measurement results of the patient 1 . Figures 3 and 4 show the results of the algometer (load in kgf), VAS and maximal mouth opening measurements respectively.

There was no significant difference between results obtained with pressure algometer before and after low level laser therapy, at each appointment $(\mathrm{p}=0.995)$. However, there was a significant difference when comparing the appointment days $(\mathrm{p}=0.000)$. The highest values were obtained between the days 9 (forth application) and 16 (sixth application) (Table 1 and Figure 3). The patient reported lower results in VAS on these three days, both before and after laser application (Figure 4). The patient indicated a significant improvement of the pain after the laser application on days 21 and 23 (seventh and eighth applications), which was not detected by algometer (Figures 3 and 4). There was an improvement in maximum mouth opening of Patient 1 . The highest value was registered on day 16 (Figure 4).

Table 1- Means, standard deviations and homogeneous groups for the pressure algometer results of the patient 1

$\begin{array}{ccccccccc}\text { Day } & 0 & 2 & 7 & 9 & 14 & 16 & 21 & 23 \\ \text { Mean } \pm \text { sd (Kg) } & 1.84 \pm 0.81 & 2.21 \pm 0.57 & 1.58 \pm 0.61 & 2.84 \pm 0.64 & 3.3 \pm 0.74 & 3.07 \pm 0.65 & 1.88 \pm 0.52 & 1.64 \pm 0.36 \\ \begin{array}{c}\text { Homogeneous } \\ \text { groups }\end{array} & \text { BC } & \text { B } & \text { C } & \text { A } & \text { A } & \text { A } & \text { BC } & \text { BC }\end{array}$

* Values followed by different letters are statistically different.

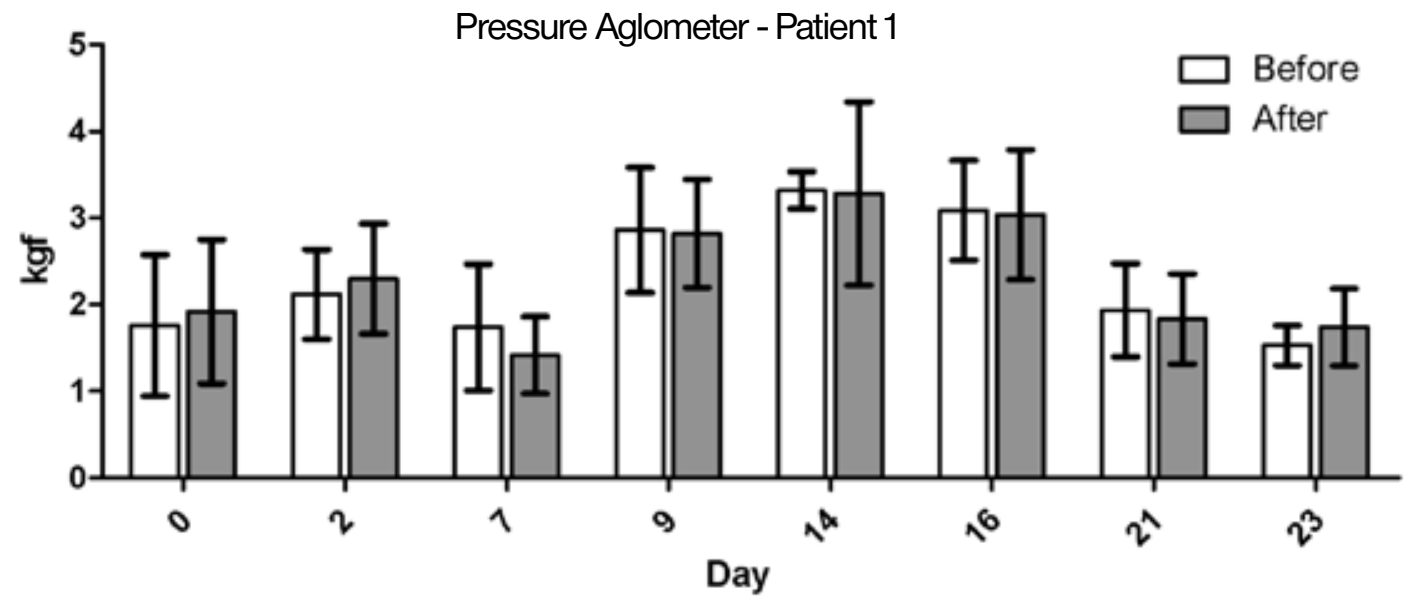

Figure 3 - Pressure algometer results for patient 1. 


\section{Patient 2}

Table 2 shows the means, standard deviations and homogeneous groups for the pressure algometer results of the patient 2 . Figures 5 and 6 illustratethe results of pressure algometer, VAS and maximal mouth opening measurements of the Patient 2 respectively.

There was no significant difference between results obtained with the pressure algometer before and after low level laser therapy, at each appointment $(\mathrm{p}=0.122)$. The figure shows slightly higher results after laser application, with the exception of day 14 (Figure $5)$, when comparing the appointment days ( $\mathrm{p}=$ 0.000 ), and the highest values were obtained on day 14 (fifth application). Except for day 9, lesser values of pain (VAS) were reported in all appointments after the laser therapy (figure 6).An improvement in maximum mouth opening was reported for Patient 2, both before and after laser application, with the highest value on the day 16 (Figure 6).

Table 2 - Means, standard deviations and homogeneous groups for the pressure algometer results of the patient 2

$\begin{array}{ccccccccc}\text { Day } & 0 & 2 & 7 & 9 & 14 & 16 & 21 & 23 \\ \text { Mean } \pm \text { sd (Kg) } & 1.54 \pm 0.58 & 2.6 \pm 0.42 & 1.32 \pm 0.32 & 2.68 \pm 0.34 & 3.22 \pm 0.58 & 2.57 \pm 0.33 & 1.68 \pm 0.37 & 1.60 \pm 0.30 \\ \begin{array}{c}\text { Homogeneous } \\ \text { groups }\end{array} & \text { C } & \text { B } & \text { C } & \text { B } & \text { A } & \text { B } & \text { C } & \text { C }\end{array}$

*Values followed by different letters are statistically different.

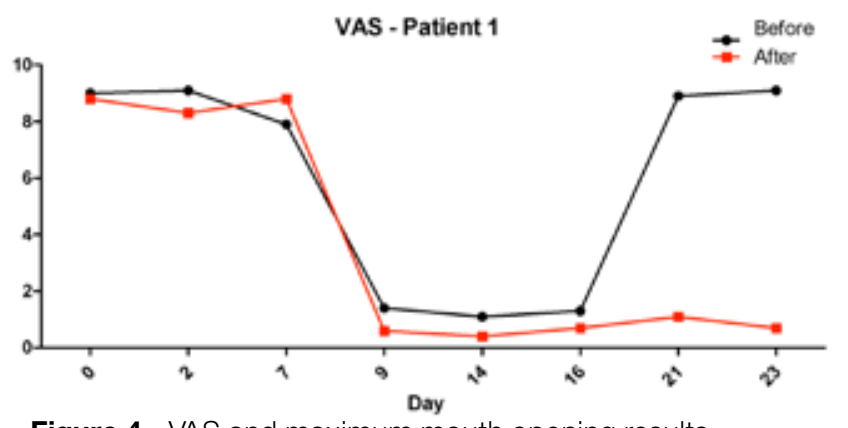

Figure 4 - VAS and maximum mouth opening results for patient 1.

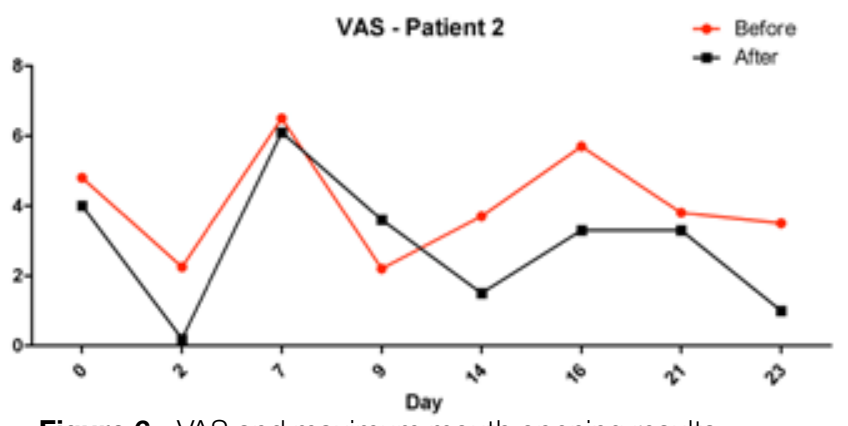

Figure 6 - VAS and maximum mouth opening results for patient 2.

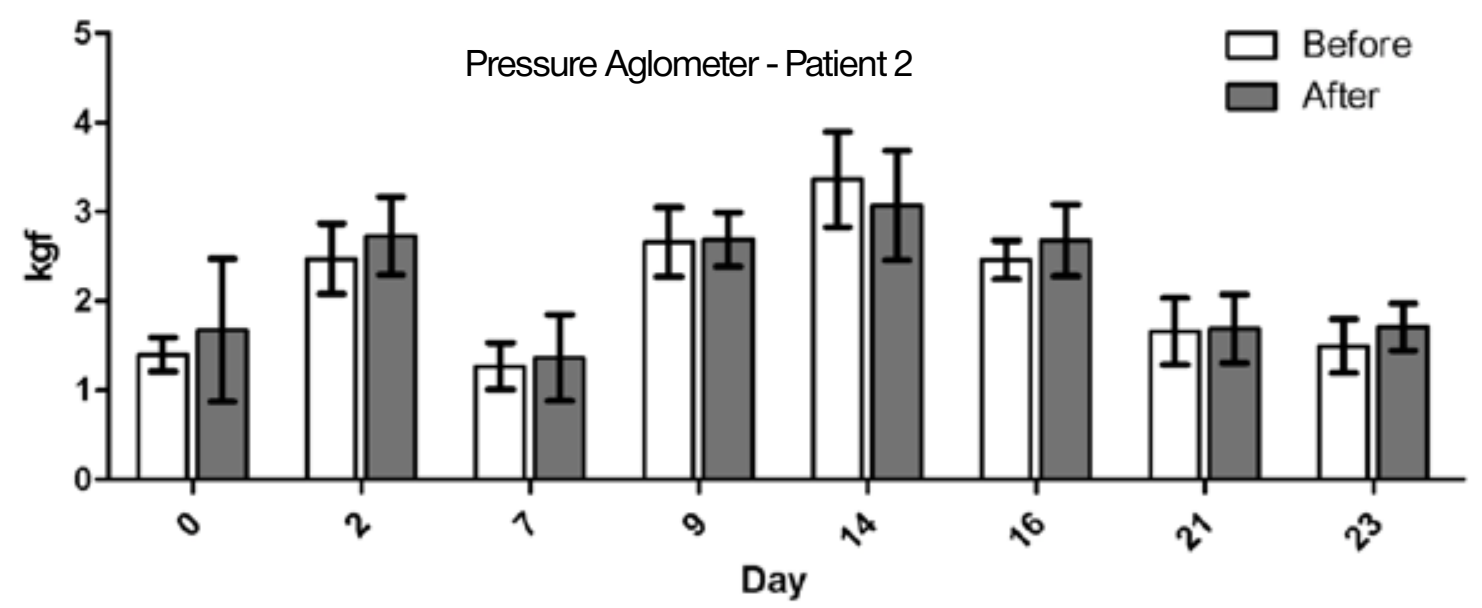

Figure 5 - Pressure algometer results for patient 2. 


\section{DISCUSSION}

Low level laser application is a complementary treatment to pain caused by TMD due to its analgesic, anti-inflammatory and muscle relaxation properties [14-17]. The results of this study are in agreement with other studies [20,32-35] that also reported the low level laser as an effective therapy in minimizing the pain symptoms triggered by the TMD. Some mechanisms of laser action are cited in the literature, as increase on the endogenous opiates liberation, decrease on the permeability of the nerve cell membrane and increase on the ATP production [14]. The reduction on the levels of creatine kinase activity, a cytokine involved in the early phase of muscle damage, and C-reactive protein, a marker of systemic inflammation, is also reported in the literature [31].

The clinical results showed in VAS figures that pain relief tends to improve after laser application. Although there are some crossings of the lines "before" and "after" in some regions, the line symbolizing the patient after treatment is usually below the one symbolizing the pain before laser application. Although the VAS scale is quite subjective, this method was already validated by the literature. The results obtained by VAS in this study are in agreement with Shinozaki study [32], which verified that laser therapy promoted immediate relaxation of the masseter and temporalis muscles with consequential relief in painful symptoms of TMD.

Moreover, the effectiveness of the treatment is noted comparing the initial (day 0) and final (day 23) pain of patients according to VAS. The patient 1 reported, on the VAS, value 9 before starting the treatment and changed to value 1 at the end. Patient 2, reported value 5 on the VAS before starting treatment and value 1 after the last laser application. These results agree with Dostalová et al. [20], which found that TMD patients undergoing treatment with laser had a reduction in VAS values after five treatment sessions. The visual analog scale is easy to use, in accordance with some studies [2629]. However, because it reflects a momentary feeling described by the patient, it should be used with caution.
Comparing the maximum mouth opening of the patients at the beginning and the end of the treatment, patient 1 had an increase of $54.25 \%$ in his maximum opening, while patient 2 increased $37.87 \%$, which demonstrates again the efficacy of laser therapy, as previously reported [20,32-35]. In this study, patient 1 had an initial maximum mouth opening of 30 $\mathrm{mm}$ that turned to $50 \mathrm{~mm}$ at the end of the treatment. Patient 2 evolved from $28 \mathrm{~mm}$ to 39 $\mathrm{mm}$. These results are in agreement with the findings of Dostalová et al. [20], who reported an improvement in mouth opening from $34 \mathrm{~mm}$ to $42 \mathrm{~mm}$.

There was no significant difference in values before and after the laser application for both patients using the pressure algometer. However, some values were slightly higher after laser therapy (Figure 5). The greater results for both patients were reported between $4^{\circ}$ and $6^{\circ}$ application, and the highest values occurred at the $5^{\circ}$ application. This similarity on the results can indicate the reliability of this method, in agreement with previous literature [22-25], which highlights this instrument as a valid way of measurement in patients with varied musculoskeletal pain syndromes, as well as in asymptomatic patients. It is suggested, nevertheless, an adaptation of the instrument for its use in the masticatory muscles, especially when these are symptomatic and recording lighter forces.

Comparisons between different methods of pain measurements should be made with caution, since pressure algometer values are specific and timely and VAS values are more subjective and correlated to the patient's emotional state. So the authors of this study believe that the three methods are complementary and provide important data. Another point worth noting is that the variations in the values obtained for the three assessment methods can be part of the natural evolution of the disease. A controlled clinical study would be required to say with greater certainty that the treatment is really effective.

The authors also believe the use of a placebo group is primordial for studies that want to evaluate the effectiveness of a therapeutic method, despite the difficulties in 
approving a project using a placebo in Research Ethics Committees. This practice should be reconsidered by the committee since the motivation for treatment, even if it does not have an active vehicle, can change the posture of the patient towards the problem, generating distortions on the results.

\section{FINAL EVALUATION OF THE CASES}

The assessment methods used are very practical, for both scientific and clinical usage, in the registry of pain before and after laser therapy. The analog pressure algometer offers a precise numerical measurement data but causes uncomfortable feeling for the patient. The VAS has the disadvantage of subjectivity. The maximum mouth opening is an objective method, which can reflect the improvement of pain symptoms. Low Level Laser therapy seems to have a beneficial effect for muscle pain of TMJ.

\section{REFERENCES}

1. Santos Tde S, Piva MR, Ribeiro MH, Antunes AA, Melo AR, Silva ED. Lasertherapy efficacy in temporomandibular disorders: control study. Braz J Otorhinolaryngol. 2010;76(3):294-9.

2. Carvalho CM, de Lacerda JA, dos Santos Neto FP, Cangussu MC Marques AM, Pinheiro AL. Wavelength effect in temporomandibular joint pain: a clinical experience. Lasers Med Sci. 2010;25(2):229-32.

3. Dworkin SF, LeResche L. Research diagnostic criteria for temporomandibular disorders: Review, criteria, examinations and specifications, criteria. J Craniomandib Disord.1992;6(4):301-55.

4. Biasotto - Gozalez DA. Abordagem interdisciplinar das disfunções temporomandibulares. São Paulo: Manole; 2005.Addy M, Hunter ML. Can tooth brushing damage your health? Effects on oral and dental tissues. Int Dent J. 2003;53(Suppl 3):177-86.

5. YAP AUJ. Depression and somatization in patients with temporomandibular disorders. J Prosthet Dent. 2002;88(5):479-84.

6. Oakley M, Vieira AR. The many faces of the genetics contribution to temporomandibular joint disorder. Orthod Craniofac Res. 2008;11(3):125-35.

7. Bianchini EMG. Articulação temporomandibular: implicações, limitações e possibilidades fonoaudiológicas. Carapicuíba: PróFono: 2000.

8. Wilding RJ, Shaikh M. Muscle activity and jaw movements as predictors of chewing performance. J Orofac Pain. 1997;11(1):24-36. Lussi A. Erosive tooth wear - a multifactorial condition of growing concern and increasing knowledge. Monogr Oral Sci. 2006;20:1-8.

9. Rizzi EC, Issa JPM, Dias FJ, Leão JC, Regalo SCH, Siessere S, et al. Low-level laser intensity application in masseter muscle for treatment purposes. Photomed Laser Surg. 2010;28(2):31-5.
10. Galdón MJ, Durá E, Andreu Y, Ferrando M, Poveda R, Bagán JV. Multidimensional approach to the differences between muscular and articular temporomandibular patients: coping, distress, and pain characteristics. Oral Surg Oral Med Oral Pathol Oral Radiol Endod. 2006;102(1):40-6.

11. Bagis B, Ayaz EA, Turgut S, Durkan R, Ozcan M. Gender difference in prevalence of signs and symptoms of temporomandibular joint disorders: a retrospective study on 243 consecutive patients. Int $\mathrm{J}$ Med Sci. 2012;9(7):539-44

12. Cooper BC, Kleinberg I. Examination of a large patient population for the presence of symptoms and signs of temporomandibular disorders. Cranio. 2007;25(2):114-26.

13. Leeuw R. Dor orofacial: guia de avaliação, diagnóstico e tratamento. 4 ed. São Paulo: Quintessence; 2010.

14. Núñez SC, Garcez AS, Suzuki SS, Ribeiro MS. Management of mouth opening in patients with temporomandibular disorders through low-level laser therapy and transcutaneous electrical neural stimulation. Photomed Laser Surg. 2006;24(1):45-9.

15. Bertolucci LE, Grey T. Clinical analysis of mid-laser versus placebo treatment of arthralgic TMJ degenerative joints. $J$ Craniomandibular Pract.1995;13(1):26-29.

16. Gray RJM, Davies SJ, Quayle AA. A clinical approach to temporomandibular disorders: A clinical approach to treatment. $\mathrm{Br}$ Dent J. 1994;177(3):101-6.

17. Kobayashi M, Kubota J. Treatment of TMJ pain with diode laser therapy. Laser Ther. 1999;1:11-8.

18. Fricton JR. The relationship of temporomandibular disorders and fibromyalgia: implications for diagnosis and treatment. Curr Pain Headache Rep. 2004;8(5):355-63.

19. Carvalho CM, de Lacerda JA, dos Santos Neto FP, Cangussu MC, Marques AM, Pinheiro AL. Wavelength effect in temporomandibular joint pain: a clinical experience. Lasers Med Sci. 2010;25(2):229-32.

20. Dostalová T, Hlinakova P, Kasparova M, Rehacek A, Vavrickova L, Navrátil L. Effectiveness of physiotherapy and gaAIAs laser in the management of temporomandibular joint disorders. Photomed Laser Surg. 2012;30(5):275-80.

21. Carrasco TG, Mazzetto M0, Mazzetto RG, Mestriner W Jr. Low intensity laser therapy in temporomandibular disorder: a phase II double-blind study. Cranio. 2008;26(4):274-81.

22. Isselee H, De Laat A, Lesaffre E, Lysens R. Short-term reproducibility of pressure pain thresholds in masseter and temporalis muscles of symptom-free subjects. Eur J Oral Sci. 1997;105(6):583-7.

23. Ohrbach R, Gale EN. Pressure pain thresholds in normal muscles: reliability, measurement effects, and topographic differences. Pain. 1989;37(3):257-63.

24. Ohrbach R, Gale EN. Pressure pain thresholds, clinical assessment, and differential diagnosis: reliability and validity in patients with myogenic pain. Pain. 1989;39(2):157-69.

25. Farella M, Michelotti A, Steenks MH, Romeo R, Cimino R, Bosman F. The diagnostic value of pressure algometry in myofascial pain of the jaw muscle. J Oral Rehabi. 2000;27(1):9-14.

26. Niemi PM, Le Bell Y, Kylmala M, Jamsa T, Alanen P. Psychological factors and responses to artificial interferences in subjects with and without a history of temporomandibular disorders. Acta Odontol Scand. 2006;64(5):300-5. 
27. Mazzetto MO, Hotta TH, Pizzo RC. Measurements of jaw movements and TMJ pain intensity in patients treated with GaAIA laser. Braz Dent J. 2010;21(4):356-60.and classification. J Prosthet Dent. 1979;42:649-53.

28. Hotta PT, Hotta TH, Bataglion C, Bataglion SA, de Souza Coronatto EA, Siéssere $\mathrm{S}$, et al. Emg analysis after laser acupuncture in patients with temporomandibular dysfunction (TMD). Implications for practice. Complement Ther Clin Pract. 2010;16(3):158-60.

29. Katsoulis J, Ausfeld-Hafter B, Windecker-Gétaz I, Katsoulis K, Blagojevic N, Mericske-Stern R. Laser acupuncture for myofascial pain of the masticatory muscles. A controlled pilot study. Schweiz Monatsschr Zahnmed. 2010;120(3):213-25.

30. Simons DG, Travell JG, Simons LS. Dor e disfunção miofascial: Manual dos pontos-gatilho. Porto Alegre: Artmed: 2005.

31. Bjordal JM, Lopes-Martins RAB, Joenson J, Iversen VV. The anti-inflammatory mechanism of low level laser therapy and its relevance for clinical use in physiotherapy. Phys Ther Rev. 2010;15(4):286-93.
32. Shinozaki EB. Avaliação eletromiográfica de pacientes com DTM após a Laserterapia. RG0. 2006;54(4):334-9.

33. Frare JC, Nicolau RA. Análise clínica do efeito da fotobiomodulação laser (GaAs - $904 \mathrm{~nm}$ ) sobre a disfunção temporomandibular. Rev Bras Fisioter. 2008;12(1):37-42

34. Ross G. Photobiomodulation in dentistry. Photomed Laser Surg. 2012;30(10):565-7.

35. Fikácková H, Dostálová T, Navrátil L, Klaschka J. Effectiveness of low-level laser therapy in temporomandibular joint disorders: A placebo-controlled study. Photomed Laser Surg. 2007;25(4):297303.

\section{Heleine Maria Chagas Rêgo (Corresponding author)}

Av. Eng. Francisco José Longo, 777

Jd. São Dimas - São José dos Campos

12245-000 - São Paulo - SP - Brazil

Date submitted: 2013 Feb 19

Email: heleine.rego@hotmail.com 